\title{
Inhibition and Adsorption impact of Leave Extracts of Cnidoscolus Aconitifolius on Corrosion of Aluminium Sheet in 1 M Hcl Medium
}

\section{*11BENEDICT U. UGI; IKAMA E. UWAH; NNANA U. UKPE}

\author{
${ }^{1}$ Corrosion and Electrochemistry Research Group, Department of Pure and Applied Chemistry \\ University of Calabar, P. M. B. 1115, Calabar, Nigeria. \\ Corresponding author: ugibenedict@gmail.com (07067921098)
}

KEYWORDS: Activation energy, Gibb's Free Energy, Langmuir adsorption, Cnidoscolus aconitifolius, Aluminium sheet.

\begin{abstract}
Corrosion inhibition in the presence of alokaloid and non alkaloid extracts of Cnidoscolus aconitifolius in $1 \mathrm{M} \mathrm{HCl}$ was studied using the weight loss and hydrogen evolution techniques at 303,313 and $333 \mathrm{~K}$. The results obtained revealed that the inhibition efficiency decreased with increase in temperature. Inhibition occurred through adsorption of the alokaloid and non alkaloid extracts molecules on the metal surface. The apparent activation energies, enthalpies and entropies of the dissolution process and the free energies and enthalpies for the adsorption process were determined and discussed. The fundamental thermodynamic functions were used to evaluate important inhibitive properties of Cnidoscolus aconitifolius.@ JASEM
\end{abstract}

\section{http://dx.doi.org/10.4314/jasem.v18 i2.24}

Introduction: Corrosion of Aluminium sheet is one of the most common forms of corrosion in acidic medium. The practical importance of such corrosion is in acid pickling of iron, chemical cleaning of scales of boilers, oil and petrochemical industries. Hydrochloric acids and Aluminium sheet are most commonly used in the industries. So this leads to researchers studying the effect of corrosion inhibitors on Aluminium sheet in hydrochloric acid environment (Sudhish et al, 2011). The inhibition of Aluminium in acid solutions by different type of organic compounds has been extensively studied. Among them very few are environmentally acceptable such as natural products i.e. extracts of various parts of plants, pharmaceutically active compounds i.e. antibiotics, antibacterial etc. (Sudhish et al, 2011).

Cnidoscolus aconitifolius, commonly known as Chaya or Tree Spinach, is a large, fast growing leafy perennial shrub that is believed to have originated in the Yucatán Peninsula of Mexico (Grubben \& Denton, 2004). The leaves are very high in protein, calcium, iron, carotene, and vitamins $\mathrm{A}, \mathrm{B}$ and $\mathrm{C}$. The leaves also contain hydrocyanic glycosides, which could cause health problems if the leaves were eaten raw. The leaves are very high in protein, calcium, iron, carotene, and vitamins $\mathrm{A}, \mathrm{B}$ and $\mathrm{C}$. The leaves also contain hydrocyanic glycosides, which could cause health problems if the leaves were

eaten raw (Grubben and Denton, 2004). In this work, we report the kinetic, activation and adsorption parameters. In addition, the adsorption isotherm for the different temperature range $(303,313$ and $333 \mathrm{~K})$ was also obtained to show the adsorption model of the inhibitor.

\section{MATERIALS AND METHODS}

In order to study the temperature effects on the performance of the alkaloid and non alkaloid extracts of Cnidoscolus aconitifolius leaves against aluminium sheet in hydrochloric acid solution without and with different concentrations of the inhibitor at 303,313 and $333 \mathrm{~K}$, the weight loss method is probably most widely used method of inhibition assessment (Ugi and Abeng, 2013). Aluminium sheet sample was taken as the same size and composition as reported earlier (Ugi et al, 2013). The sheets were mechanically press-cut into $4.00 \mathrm{x}$ $0.08 \times 5.00 \mathrm{~cm}$ and $4 \mathrm{~cm} \times 0.008 \mathrm{~cm} \times 2.0 \mathrm{~cm}$ samples. The former meant for weight loss analysis while the later for the hydrogen evolution analysis These were polished with different grades of emery paper, degreased in absolute ethanol, dried in acetone and stored in a moisture free desiccator prior to use ( Uwah et al, 2013) and all weighing was done with ADAM PGW - 253e digital analytical balance. The corrosion rates $\left(\mathrm{C}_{\mathrm{R}}\right)$ of the Aluminium was calculated graphically using the Microsoft Excel spray sheet where a graph of the weight loss per surface area

*Corresponding author: ugibenedict@gmail.com 
(mg/cm2 ) was plotted against time of exposure (hrs) and the corrosion rate values obtained from the slope of the graph that was obtained from the Trendline option of the spray sheet Okafor et al, 2012; Uwah et al, 2013 and Ugi and Uwah, 2012). The surface coverage $(\theta)$ and Inhibition efficiency $(\mathrm{E} \%)$ were determined using the following equations;

$\theta=\frac{W o-W i}{W o} \quad \mathrm{E} \%=\frac{W o-W i}{W o} \times 100$

where wo and wi are the weight loss values in presence and absence of inhibitor, respectively (Loto, 2011 and Nnnana et al., 2010).

\section{RESULTS AND DISCUSSION}

Weight loss data and analysis: The percentage inhibition efficiency of AECAL and NAECAL extracts has been evaluated by weight loss method at $30^{\circ} \mathrm{C}$ (Table 1, Figs. 1 and 2). It was observed to increase with increase in concentration of the inhibitor and this behavior indicates that the adsorbed inhibitor molecules formed a barrier film on the aluminium surface (Santhini and Jeyaraj, 2012; Dada et al., 2012 and Ugi and Abeng, 2013) and it decreases with increase in temperature. According to Saratha and Meenakshi, (2010), decrease in inhibition efficiency with increase in temperature indicates physisorption of inhibitor on the corroding metal surface. It is also attributed to increase in the solubility of the protective films and of any reaction products precipitated on the surface of the metal (Santhini and Jeyaraj, 2012).

Adsorption Isotherm: According to Langmuir adsorption isotherm, $\theta$ is related to equilibrium adsorption constant

(Kads) and $\mathrm{C}$ by the equation: $\frac{C}{\theta}=\frac{1}{K a d s}+$ C

Fig. 3 shows the straight lines of $\mathrm{C} / \theta$ vs. $\mathrm{C}$ at different temperatures. The parameters obtained from $\mathrm{C} / \theta$ vs. $\mathrm{C}$ plots were listed in Table 2 . These results show that all the linear correlation coefficients $\left(\mathrm{R}^{2}\right)$ are almost equal to 1 and the slopes are close to 1 , which confirmed that the adsorption of the plant extract on aluminium surface good obeyed Langmuir adsorption isotherm Hui et al., (2013) and Pradeep \& Mohana, (2013).. Table 2 revealed that $\mathrm{K}_{\mathrm{ads}}$ decreased with increasing temperature, which indicated that the plant extract is easily and strongly adsorbed onto the aluminium sheet surface at lower temperature, however, the adsorbed extract appears to desorb from aluminium sheet surface at higher temperature (Fig 4).

Table 1: Inhibition efficiency of different concentrations of AECAL and NAECAL extracts for corrosion of aluminium in $1 \mathrm{M} \mathrm{HCl}$ solution evaluated by weight loss technique

\begin{tabular}{cccclcc}
\hline \multicolumn{3}{c}{ AECAL } \\
\hline Systems & $\begin{array}{c}\mathrm{C}_{\mathrm{R}}\left(\mathrm{mg} / \mathrm{cm}^{2} /\right. \\
\mathrm{min})\end{array}$ & $\begin{array}{c}\text { Surface } \\
\text { Coverage }(\Theta)\end{array}$ & $\eta(\%)$ & $\begin{array}{l}\mathrm{C}_{\mathrm{R}}\left(\mathrm{mg} / \mathrm{cm}^{2} /\right. \\
\min )\end{array}$ & $\begin{array}{l}\text { Surface } \\
\text { Coverage }(\Theta)\end{array}$ & $\begin{array}{c}\eta \\
(\%)\end{array}$ \\
Blank $(1 \mathrm{M} \mathrm{HCl})$ & 0.472 & - & - & 0.472 & - & - \\
$0.1 \mathrm{~g} / \mathrm{L}$ & 0.207 & 0.562 & 56.2 & 0.441 & 0.066 & 6.6 \\
$0.5 \mathrm{~g} / \mathrm{L}$ & 0.155 & 0.671 & 67.1 & 0.377 & 0.201 & 20.1 \\
$0.7 \mathrm{~g} / \mathrm{L}$ & 0.133 & 0.718 & 71.8 & 0.373 & 0.210 & 21.0 \\
$1.0 \mathrm{~g} / \mathrm{L}$ & 0.131 & 0.722 & 72.2 & 0.357 & 0.244 & 24.4 \\
$2.0 \mathrm{~g} / \mathrm{L}$ & 0.099 & 0.791 & 79.1 & 0.297 & 0.371 & 37.1 \\
\hline
\end{tabular}

Table 2: Adsorption parameters for aluminium in $1 \mathrm{M} \mathrm{HCl}$ solutions containing AECAL and NAECAL

\begin{tabular}{|c|c|c|c|c|c|c|c|c|}
\hline \multirow[b]{2}{*}{$\begin{array}{c}\text { Temp. } \\
\text { (K) }\end{array}$} & \multicolumn{3}{|c|}{ AECAL } & \multicolumn{5}{|c|}{ NAECAL } \\
\hline & $\begin{array}{l}\text { Equil. Const. } \\
\mathrm{k}(\mathrm{g} / \mathrm{L})\end{array}$ & $\begin{array}{l}\text { Corr. Coef. } \\
\text { (R2) }\end{array}$ & Slope & $\begin{array}{l}\Delta \mathrm{G}^{*} \text { ads } \\
(\mathrm{KJ} / \mathrm{mol})\end{array}$ & $\begin{array}{c}\text { Equil. } \\
\text { Const. k (g/L) }\end{array}$ & $\begin{array}{c}\text { Corr. } \\
\text { Coef. (R2) }\end{array}$ & Slope & $\begin{array}{l}\Delta \mathrm{G}^{*} \text { ads } \\
(\mathrm{KJ} / \mathrm{mol})\end{array}$ \\
\hline 303 & 23.981 & 0.9993 & 1.061 & -444.22 & 9.569 & 0.9976 & 1.336 & -315.78 \\
\hline 313 & 9.066 & 0.9959 & 1.123 & -318.40 & 5.711 & 0.9956 & 1.401 & -251.65 \\
\hline 333 & 3.050 & 0.9514 & 1.184 & -171.33 & 4.953 & 0.9867 & 1.477 & -245.85 \\
\hline
\end{tabular}




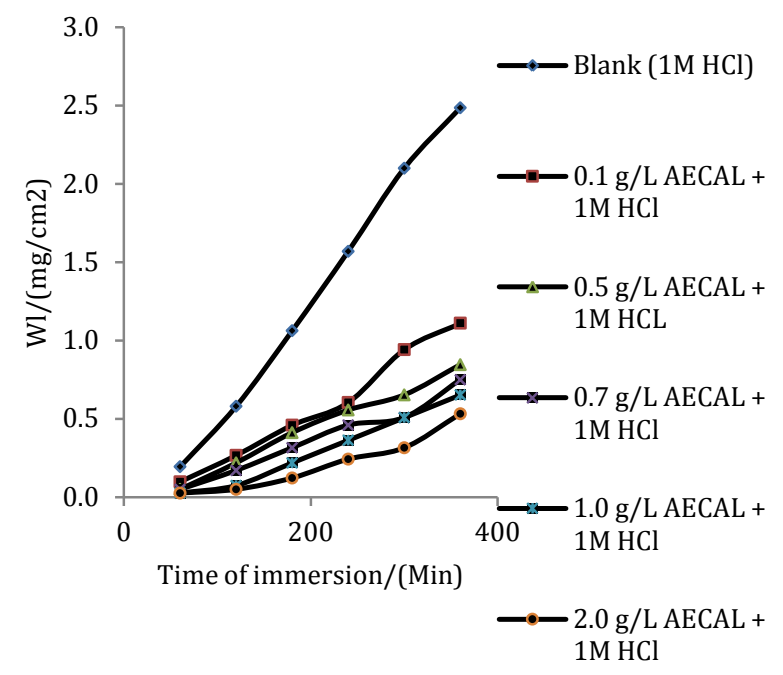

(a)

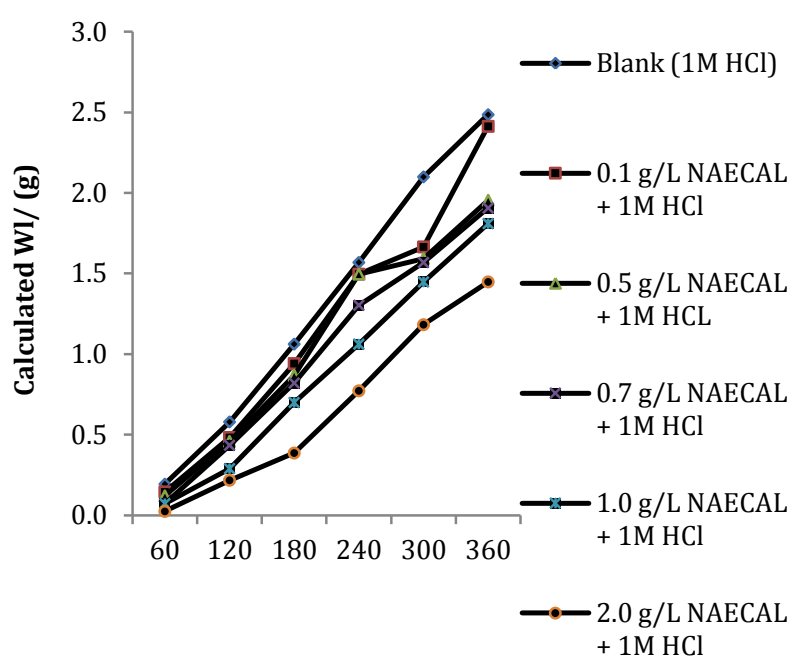

Time of immersion/(min)

(b)

Fig. 1: Variation of weight loss with immersion time for aluminium samples in $1 \mathrm{M} \mathrm{HCl}$ solution containing (a) AECAL and (b) NAECAL

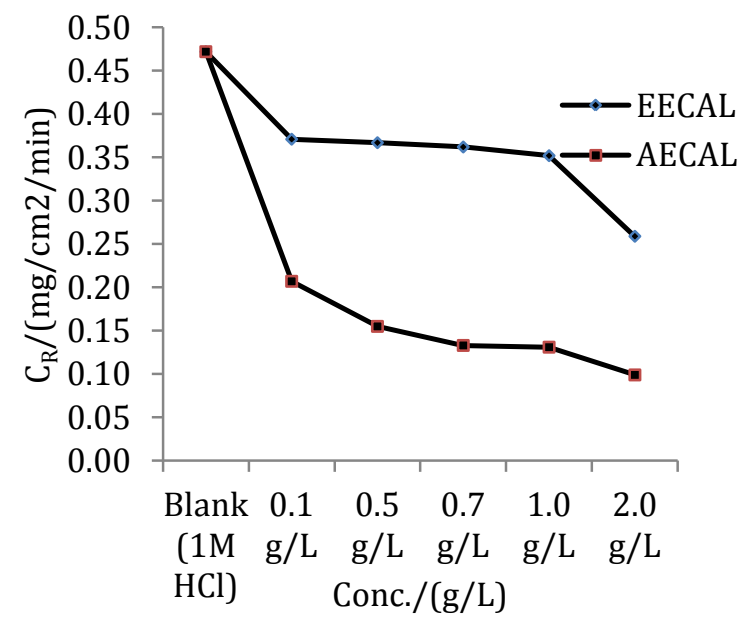

(a)

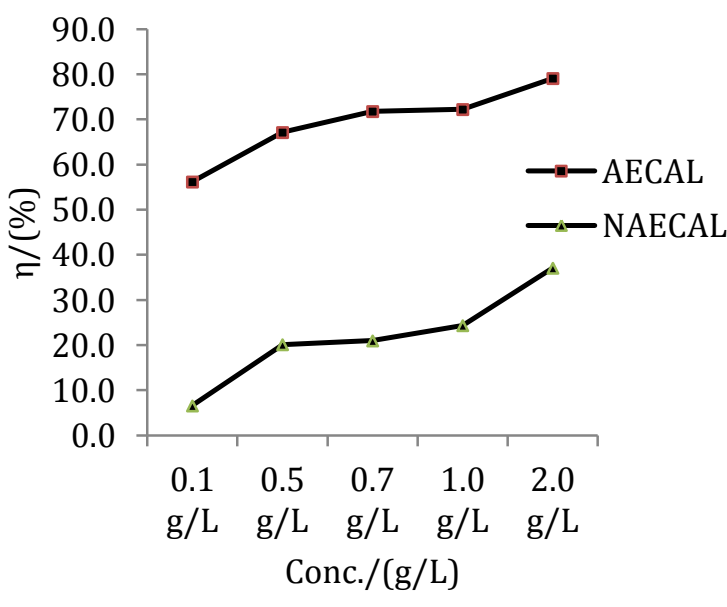

(b)

Fig. 2: Variation of (a) $\mathrm{C}_{\mathrm{R}}$ and (b) IE(\%) with AECAL and NAECA extract concentrations for Aluminium samples in $1 \mathrm{M} \mathrm{HCl}$ solution 


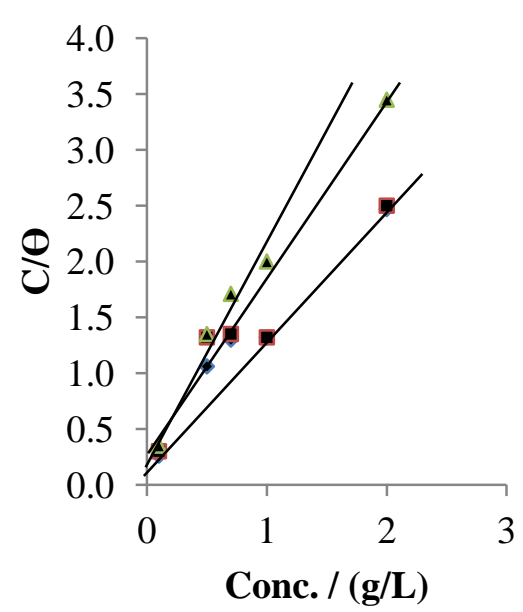

(a)

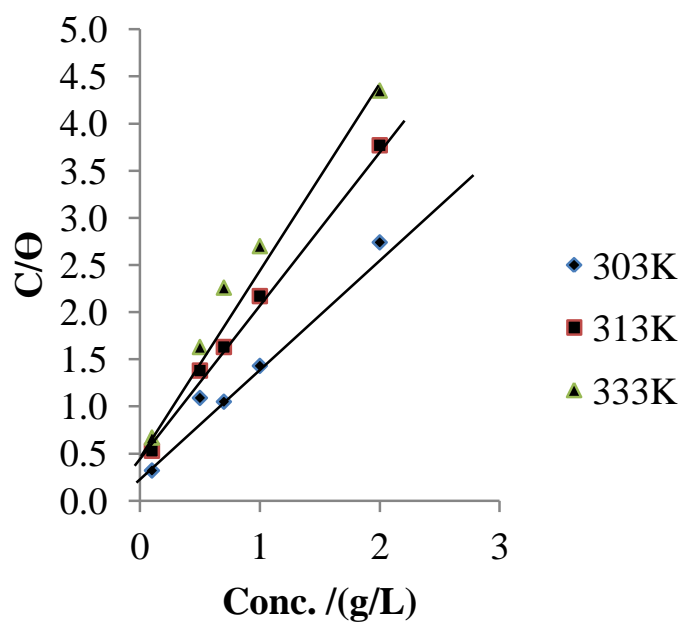

(b)

Fig. 3 Langmuir adsorption plots for $\mathrm{Al}$ in $1 \mathrm{M} \mathrm{HCl}$ at different temperatures in presence of different concentrations of (a) AECAL and (b)NAECAL

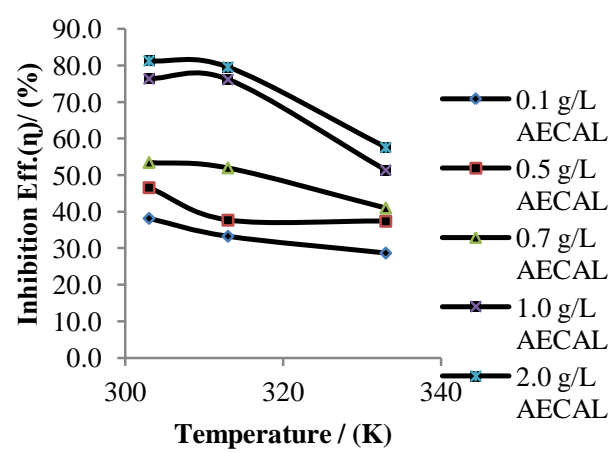

(a)

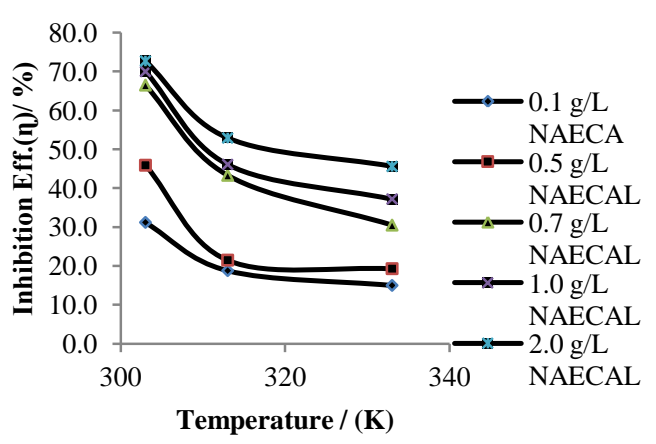

(b)

Fig. 4: Variation in inhibition efficiency against Temp. (K) of (a) AECAL and (b) NAECAL on aluminium sheet in $1 \mathrm{M} \mathrm{HCl}$

Thermodynamic consideration: The standard adsorption free energy $\left(\Delta \mathrm{G}^{\mathrm{o}}{ }_{\mathrm{ads}}\right)$ was obtained according to Hui et al., (2013), Patel et al., (2013); Pradeep \& Mohana, (2013): $\Delta \mathrm{G}_{\text {ads }}^{\mathrm{o}}=-\mathrm{RT}$ $\ln \left(55.5 \mathrm{~K}_{\mathrm{ads}}\right)$ where $\mathrm{R}$ is the gas constant $(\mathrm{R}=8.314 \mathrm{~J}$ $\mathrm{K}-1), \mathrm{T}$ is the absolute temperature, $\mathrm{K}_{\mathrm{ads}}$ is the equilibrium constant, respectively. The thermodynamic parameter, $\Delta \mathrm{G}_{\text {ads }}^{\mathrm{o}}$ obtained from equilibrium constant derived from Langmuir isotherm plots is listed in Table 2. The large negative values of $\Delta \mathrm{G}_{\text {ads }}^{\mathrm{o}}$ reveal that the adsorption process took place spontaneously and the adsorbed layer on the surface of aluminium is highly stable and the process is a physical adsorption process (Hui et al, 2013). It is worth noting that $-\Delta \mathrm{H}_{\text {ads }}^{\mathrm{o}} / 2.303 \mathrm{R}$ is the slope of the straight line from plot of $\log \left(\operatorname{lnC}_{R} / T\right)$ vs. $1 / T$ and the intercept $\log (R / h)+\Delta S / 2.303 R$, from which the values of $\Delta \mathrm{H}$ and $\Delta \mathrm{S}$ were calculated and given in Table 4 according to the transition state equation (Abeng et al., 2013):

$$
R_{c}=\frac{K T}{h} \exp \left(\frac{\Delta S *_{i}}{R}\right) \exp \left(\frac{-\Delta H *_{i}}{R T}\right)
$$

where $\mathrm{R}$ is the gas constant $(\mathrm{R}=8.314 \mathrm{~J} \mathrm{~K}-1), \mathrm{T}$ is the absolute temperature, $\mathrm{h}$ is the plank constant, respectively. The straight line $\ln _{R} / T$ vs. $1 / T$ is shown in Fig. 5a and b. Inspection of these data reveals that the positive signs of enthalpy $(\Delta \mathrm{H})$ reflect the endothermic nature of dissolution process. In this work, from the average $\Delta \mathrm{H}^{*}$ values calculated, the absolute values of enthalpy are low approaching those of typical physisorption. The shift towards negative value of entropy $(\Delta \mathrm{S})$ imply that the 
activation complex in the rate determining state represents association rather than dissociation, meaning that the disordering decreases on going from reactants to the activation complex (Uwah et al., 2013; Ugi \& Uwah, 2012). Negative values of $\Delta S^{*}$ indicates that entropy decreases upon achieving the transition state, which often indicates associative mechanism according to Hui et al., (2013) and Pradeep \& Mohana, (2013).

The activation energy at different concentration of the inhibitor in $1 \mathrm{M} \mathrm{HCl}$ was calculated by plotting $\log \mathrm{C}_{\mathrm{R}}$ vs. 1/T (Fig. $5 \mathrm{c}$ and $\mathrm{d}$ and Table 3 ). $\mathrm{E}_{\mathrm{a}}$ values for the inhibited systems were higher than those for the uninhibited system indicating that all the inhibitors inhibited the aluminium dissolution. Low I.E were observed at elevated temperatures and this suggests a physical adsorption in the first stage (Guster and Singh, 2004; Keiser et al., 2002; Camille et al., 2003). This can also be attributed to an appreciable decrease in the adsorption of the inhibitor on the mild steel surface with increase in temperature.

Table 3: Thermodynamic result for AECAL and NAECAL extracts for corrosion of aluminium in $1 \mathrm{M} \mathrm{HCl}$ solution

\begin{tabular}{|c|c|c|c|c|c|c|}
\hline & \multicolumn{2}{|c|}{ NAECAL } & \multicolumn{4}{|c|}{ AECAL } \\
\hline System & $\begin{array}{l}\mathrm{Ea} \\
(\mathrm{KJ} / \mathrm{mol})\end{array}$ & $\begin{array}{l}\Delta \mathrm{H}^{*} \text { ads } \\
(\mathrm{KJ} / \mathrm{mol})\end{array}$ & $\begin{array}{l}\Delta \mathrm{S}^{*} \text { ads } \\
(\mathrm{KJ} / \mathrm{mol})\end{array}$ & $\begin{array}{l}\mathrm{Ea} \\
(\mathrm{KJ} / \mathrm{mol})\end{array}$ & $\begin{array}{l}\Delta \mathrm{H}^{*} \text { ads } \\
(\mathrm{KJ} / \mathrm{mol})\end{array}$ & $\begin{array}{l}\Delta \mathrm{S}^{*} \text { ads } \\
(\mathrm{KJ} / \mathrm{mol})\end{array}$ \\
\hline Blank & 10.6 & 9.6 & -19.1 & 10.6 & 9.6 & -19.1 \\
\hline $0.1 \mathrm{~g} / \mathrm{L}$ & 11.5 & 11.7 & -21.1 & 11.2 & 9.6 & -19.0 \\
\hline $0.5 \mathrm{~g} / \mathrm{L}$ & 12.3 & 12.4 & -21.9 & 11.3 & 10.0 & -19.4 \\
\hline $0.7 \mathrm{~g} / \mathrm{L}$ & 13.5 & 12.5 & -21.9 & 11.6 & 12.4 & -21.9 \\
\hline $1.0 \mathrm{~g} / \mathrm{L}$ & 13.6 & 12.5 & -21.9 & 13.6 & 12.5 & -21.9 \\
\hline $2.0 \mathrm{~g} / \mathrm{L}$ & 14.1 & 14.6 & -24.0 & 14.0 & 13.3 & -22.8 \\
\hline
\end{tabular}

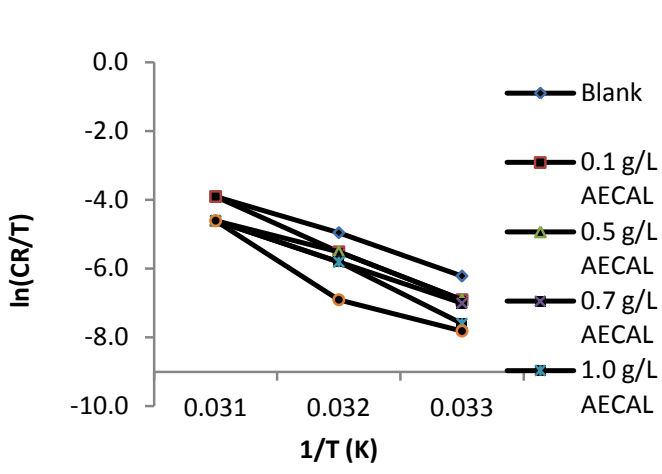

(a)

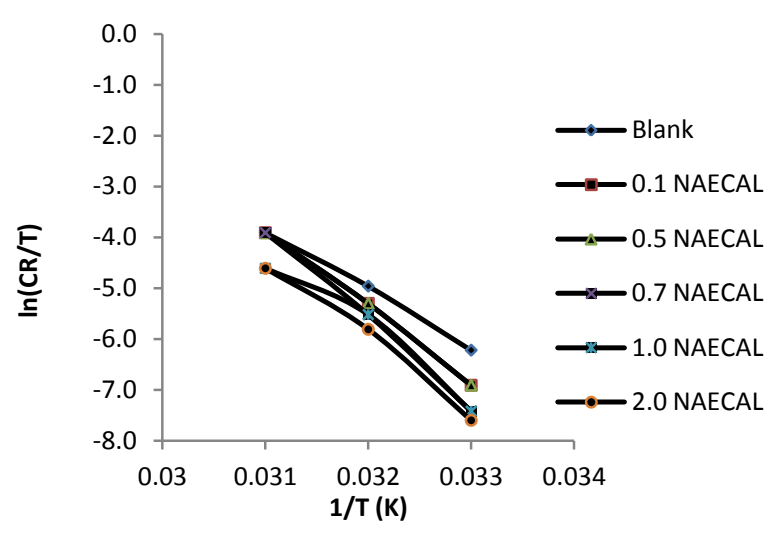

(b)

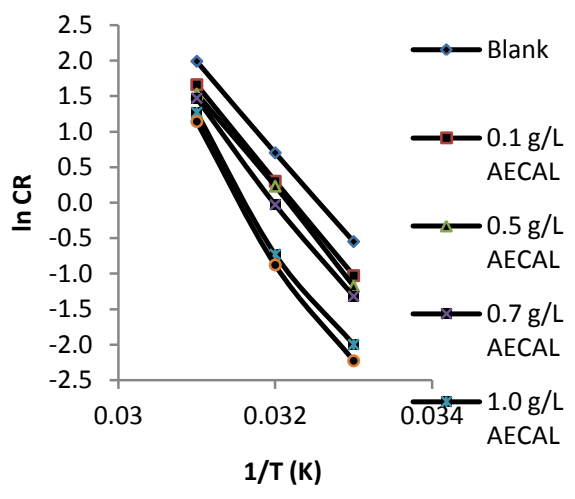

(c)

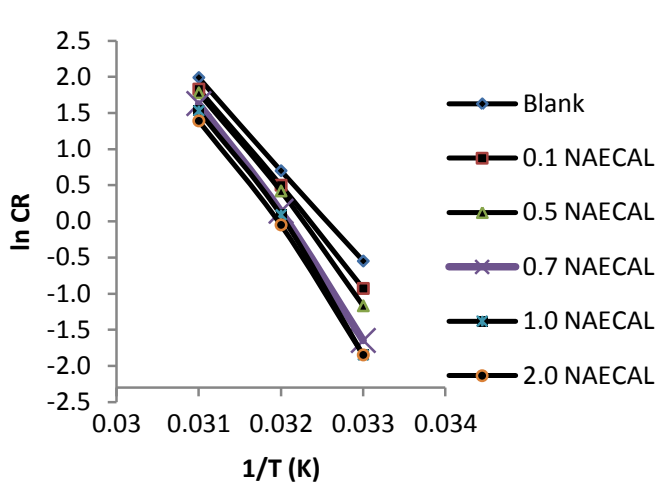

(d)

Fig. 5: ( $a$ and b) Eyring transition state and ( $c$ and d) Arrhenius plots for AECAL and NAECAL extracts for corrosion of aluminium in $1 \mathrm{M} \mathrm{HCl}$ solution. 
Conclusion: Alkaloid and Non alkaloid extracts of Cnidoscolus aconitifolius leaves are good inhibitor for aluminium in $1 \mathrm{M} \mathrm{HCl}$ mediun. IE\% increases with increasing leave extract concentration but with AECAL (79.1\%) showing better inhibition than NAECAL (37.1\%), Because the leaves of Cnidoscolus aconitifolius plant introduced in this experiment are not frequently consumed by both man and animals, the evaluation as stated above of such leaves will find an average friendly alternative and commercial use in the protection of aluminium sheets from the corrosion by the mineral acids like $\mathrm{HCl}$. Both extracts obeyed Langmuir adsorption isotherm as observed from the regression values obtained which are near the value of 1 and the adsorption process followed a mechanism of physical adsorption.

\section{REFERENCE}

Abeng, F. E., Ekpe, U. J. Ikeuba, A. I. , Ugi B. U. and Nna P. J. (2013) "Inhibitive action of Alkaloids and Non alkaloids extracts of Phyllanthus amarus on the Corrosion of Mild Steel in 2.0 M HCl Solution". Global Journal of Pure \& Applied Sciences. 19 (2013): 107 - 117.

Camille Y. J, Gang C, Sheng D. \& Singh P. M. (2003) "Solubility in the $\mathrm{NaOH}-\mathrm{Na} 2 \mathrm{CO} 3$ Na2SO4-Na2SO3-Na2S2O3-Na2S-H2O System, a Simulated Black Liquor Recovery Boiler Smelt", Ind. \& Engr. Chem. Res. 42(18): 42284233.

Dada, A. O., Olalekam, A. P., Olatunya, A. M. \& Dada, O. (2012). "Langmuir, Freundlich, Temkin and Dubinin - Radushkevich isotherms studies of equilibrium sortion of $\mathrm{Zn} 2+$ unto Phosphoric acid modified rice husk." ISOR Journal of Applied Chemistry. 3(1): 38 - 45

Grubben G. J. \& Denton O. A. (2004). Plant Resources of Tropical Africa. 2: Vegetables. PROTA Foundation. Wisley pub. pp. 201.

Gustaf B. \& Singh P. M. (2004) "Susceptibility of Stainless Steel Alloys to Crevice Corrosion in Chlorine Dioxide Bleach Plants", Corrosion Science, 46(9), 2159-2182.

Hui, C., Zhenghao, F., Jinling, S., Wenyan, S. \& Qi, X. (2013). " Corrosion inhibition of mild steel by Aloes extract in $\mathrm{HCl}$ solution medium.," Int. J. electrochem. Sci., 8(2013): 720 - 734
Keiser J. R., Singbeil D. L., Sarma G. B., Choudhury K. A., Singh P. M., Hubbard C. R., Swindeman R. W., Ely T. M., Kish J. R., Kenik E. A., Maziasz P. J., \& Bailey S. E. (2002) "Comparison of cracking in recovery boiler composite floor and primary air port tubes", TAPPI Journal, 85(2): 163 - 167.

Loto, C. A. (2011) "Inhibition effect of Tea ( Camellia Sinensis) extract on the corrosion of Mild steel in dilute sulphuric acid" Journal of Material \& Environmental Science. 2 ( 4) : 335 344

Nnanna L. A., Onwuagba B. N., Mejeha I. M. and Okeoma K. B. ( 2010) “Inhibition effects of some plant extracts on the acid corrosion of aluminium alloy" African Journal of Pure \& Applied Chemistry. 4 (1): $011-016$.

Okafor, P.C., Ebiekpe, V.E., Azike, C.F., Egbung, G.E., Brisibe, E. A. \& Ebenso, E.E. (2012) "Inhibitory action of Artemisia annua extracts and artemisinin on the corrosion of mild steel in H2SO4 solution", International Journal of Corrosion, 12: 132-137

Patel N. S., Jauhariand S., Mehta G. N., Ad-Deyab S. S., Warad I. \& Hammouti B. (2013). "Mild Steel Corrosion by Various Plant Extracts in $0.5 \mathrm{M}$ Sulphuric acid". Int. J. of Electrochem. Sci., 8(2013): $2635-2655$.

Pradeep, K. C. B. \& Mohana, K. N. (2013). "Adsorption and thermodynamic characteristics of Plumeria rubra plant extracts on mild steel corrosion in industrial water medium". International Research Journal of Pure \& Applied Chemistry, 3(4): 330 - 346.

Santhini, N. \& Jeyaraj, T. (2012). "The inhibition effect of [3-(4-hydroxy-3-methoxy-phenyl)-1phenyl-propenone] on the corrosion of the aluminium in alkaline medium". J. Chem. Pharm. Res., 4(7): 3550 - 3556

Saratha R., \& Meenakshi R. (2010) “ Corrosion inhibitor: A plant extract. Der Pharma. Chemica. 2(1): $287-294$

Sudhish K. Shukla, and Eno E. Ebenso (2011) Corrosion Inhibition, Adsorption Behavior and Thermodynamic Properties of Streptomycin on Mild Steel in Hydrochloric Acid Medium. Int. J. Electrochem. Sci. 6 (2011): 3277 - 329 
Ugi B. U. and Uwah, I. E. (2012). Investigation into the corrosion inhibition effects of Alkaloid and Non alkaloid extracts of Andrographis paniculata (King bitters) leaves on mild steel in $0.5 \mathrm{M} \mathrm{HCl}$. International Journal of Natural and Applied Sciences (IJNAS). 7(1\&2): 1-12

Ugi, B. U. and Abeng, F. E. (2013) Corrosion Inhibition Effects and Adsorption Characteristics of Ethanol Extract of King Bitters Root (Andrographis paniculata) on Mild Steel in 1.0 $\mathrm{M} \mathrm{HCl}$ and $\mathrm{H} 2 \mathrm{SO} 4$ Acid Media. Fountain Journal of Natural and Applied sciences. 2(2): 10 $-21$

Ugi, B. U., Abeng, F. E and Uwah, I. E. (2013).“Andrographis paniculata (King bitters) as non toxic corrosion inhibitor on Aluminium in $0.5 \mathrm{M} \mathrm{HCl}$ and $\mathrm{H} 2 \mathrm{SO} 4$ acidic media". Journal of Physical Sciences and Environmental Safety. 3(1): $96-111$

Uwah I. E, Ugi B. U, Ikeuba A. I. \& Essien U. B. (2013) "Costus afer Leave Extract as Nontoxic Corrosion Inhibitor in $5 \mathrm{M} \mathrm{H} 2 \mathrm{SO} 4$ solution". Global Journal of Pure \& Applied Sciences. 19 (2013): 119 - 127.
Uwah, I. E, Ugi, B. U, Okafor P. C. \& Ikeuba A. I. (2013) "Comparative study of corrosion inhibition and adsorption characteristics of ethanol extracts of Andrographis paniculata (King bitters) and Vernonia amygdalina (Bitter leaf) on Mild Steel in $\mathrm{HCl}$ solution" International. Journal of Applied Chemistry (IJAC). 9. ( 1): $73-88$

Uwah, I. E., Ikeuba, A. I., Ugi B. U. and Udowo V. M. (2013) "Comparative study of the inhibition effects of alkaloid and non-alkaloid fractions of the ethanolic extracts of Costus afer stem on the corrosion of mild steel in $5 \mathrm{M} \mathrm{HCl}$ solution". Global Journal of Pure \& Applied Sciences. 19 (2013): $23-31$.

Uwah, I. E., Ugi , B. U., Ikeuba A. I. and Etuk K. E. (2013) " Evaluation of the inhibitive action of eco-friendly benign Costus afer stem extract of corrosion of mild steel in $5 \mathrm{M} \mathrm{HCl}$ solutions". International Journal of Development and Sustainability (IJDS). 2(3): 1970 - 1981 